\title{
Hierarchical ZnO nanorod-on-nanosheet arrays electrodes for efficient CdSe quantum dot-sensitized solar cells
}

\author{
Long-Bin Li, Wu-Qiang Wu, Hua-Shang Rao, Hong-Yan Chen ${ }^{*}$, Hao-Lin Feng, Dai-Bin Kuang ${ }^{*}$ \\ and Cheng-Yong $\mathrm{Su}$
}

\begin{abstract}
Two-dimensional (2D) ZnO nanosheet arrays were prepared via vanadium (V)-doping assisted hydrothermal method, and then the nanosheet was successfully converted to a nanorod-on-nanosheet $\mathrm{ZnO}$ hierarchical structure by treating with $\mathrm{Na}_{2} \mathrm{~S}$ solution and subsequent hydrothermal reaction. Hierarchical films with different nanorod growth time (1-8 h) were prepared and their photovoltaic properties were also investigated after electrodeposition of CdSe quantum dots. For the hierarchical nanorod-on-nanosheet $\mathrm{ZnO}$ films, increasing the $\mathrm{ZnO}$ nanorod growth time can enormously enlarge the length of branched nanorods and light-scattering ability, resulting in better light-harvesting efficiency and higher photo-generated electron concentration, which leads to higher short-circuit current density $\left(J_{\text {sc }}\right)$ and open-circuit voltage $\left(V_{o c}\right)$. However, further increasing nanorod growth time to $8 \mathrm{~h}$ leads to the over-dense coverage of nanorods, which is harmful for light-harvesting efficiency and leads to severe electron recombination, eventually diminishes the power conversion efficiency (PCE). With the optimized nanorod modification and $\mathrm{Cu}_{2} \mathrm{~S}$ counter electrode, the PCE reaches a maximum value of $4.26 \%$, which to the best of our knowledge, is among the highest PCE record for CdSe sensitized solar cells based on $\mathrm{ZnO}$ photoanodes.
\end{abstract}

Keywords: hierarchical $\mathrm{ZnO}$, nanosheet, nanorod, CdSe, quantum dot-sensitized solar cells

\section{INTRODUCTION}

In the past decade, quantum dot sensitized solar cells (QDSSCs) have attracted superb attention and been considered as promising candidates for practical solar energy application due to their environment-friendly fabrication, low-cost as well as high efficiency [1-4]. It is well known that the morphology, size, and structure of photoanode materials play an important role in the sensitizer loading amount, light scattering, as well as electron transport and recombination properties, which determine the overall photovoltaic performance of QDSSCs to a great extent. Many kinds of metal oxide semiconductors have been employed as photoanode materials for QDSSCs, such as $\mathrm{TiO}_{2}$ [5-9], $\mathrm{ZnO}$ [10-13], $\mathrm{SnO}_{2}$ [14,15], and $\mathrm{Zn}_{2} \mathrm{SnO}_{4}$ $[16,17]$. Among them, $\mathrm{ZnO}$ has been considered to be a recommendable alternative to the most competitive $\mathrm{TiO}_{2}$ [5,18-21] for its intrinsic electronic and electrochemical advantages, and the highest power conversion efficiency (PCE) record for ZnO based QDSSCs has already been promoted to $6.20 \%$ [13]. Two most attractive properties of $\mathrm{ZnO}$ are the excellent electron mobility and the anisotropic growth $[4,22]$. $\mathrm{ZnO}$ has the highest reported electron mobility $\left(200-1000 \mathrm{~cm}^{2} \mathrm{~V}^{-1} \mathrm{~s}^{-1}\right)[4,23]$ among the various candidates of photoanode materials, which is more than 1 order of magnitude larger than $\mathrm{TiO}_{2}\left(0.1-1.0 \mathrm{~cm}^{2} \mathrm{~V}^{-1} \mathrm{~s}^{-1}\right)$ [24]. Meanwhile, the ease of crystallization and anisotropic growth of $\mathrm{ZnO}$ allows the rich family of $\mathrm{ZnO}$ nanostructures, including rods [11,25], tubes [26,27], sheets $[28,29]$, rings [30], hollow spheres [31,32], tetrapods [13], nanourchins [33] and many other hierarchical structures [34-38]. Nanorod (NR) is still the easiest prepared and most commonly used morphology in $\mathrm{ZnO}$ photoanode materials. Though NR structure exhibits superior electron transporting ability due to its one-dimensional architecture, the drawback of NR is apparent that the loading amount of sensitizers is insufficient because of its poor surface area. Hence, hierarchical assembly of $\mathrm{ZnO}$ structures 
has received increasing research interest because of their synergistic merits merged from the ingenious combination of specific structures. For example, Gao et al. [39] fabricated a novel hierarchical structure by decorating $\mathrm{ZnO}$ NRs with $\mathrm{ZnO}$ nanoparticles. Such a structure combined the high surface area of nanoparticles and the excellent electron transporting property of NRs, leading to a significant increase of PCE as compared to that based on $\mathrm{ZnO}$ NRs in dye sensitized solar cells (DSSCs). In recent years, hierarchical $\mathrm{ZnO}$ materials have also been employed in QDSSCs. Kim et al. [40] fabricated a nanosheet (NS)-NR combined hierarchical $\mathrm{ZnO}$ nanostructure, and demonstrated that the additional branched NSs can improve both the surface area and diffuse reflectance ability, resulting in $25 \%$ PCE enhancement for CdS/CdSe co-sensitized QDSSCs. On balance, hierarchical materials have shown their enormous prospect in enhancing the performance of QDSSCs.

On the other hand, NSs have exhibited prominent PCE values in DSSCs due to their high surface area and fast electron transporting pathways $[29,41]$. However, most of the NSs were densely packed, which seems to have no sufficient interspaces for further growth of branches on the surface of sheets. Recently, Gupta et al. [42] reported a facile hydrothermal fabrication of single-crystalline two-dimensional (2D) ZnO NSs by vanadium (V)-doping. Interestingly, the as-prepared NSs were vertically aligned and also showcasing a wide-open porous network and distinct interspaces between adjacent sheets. Zhang et al. [43] developed a new method to prepare hierarchical three-dimensional (3D) $\mathrm{ZnO}$ nanostructures by treating nanorod arrays with $\mathrm{Na}_{2} \mathrm{~S}$ solution, which was appropriate for in-situ depositing $\mathrm{ZnO}$ seeds on smooth single-crystalline structures. It would be interesting to treat the V-doped NS film with $\mathrm{Na}_{2} \mathrm{~S}$ solution and conduct subsequent hydrothermal growth of $\mathrm{ZnO} \mathrm{NRs}$ to find whether it could be converted to a hierarchical structure.

For the purpose of verifying the above concept, we first prepared the 2D V-doped NS films on fluorine doped tin oxide (FTO) glass and then dipped them into $\mathrm{Na}_{2} \mathrm{~S}$ solution. This process could introduce a uniform ZnS layer by ionexchanging on the surface of the ZnO NSs, and after annealing at high temperature in air the $\mathrm{ZnS}$ layer would then convert into a $\mathrm{ZnO}$ nanocrystal shell. Such $\mathrm{ZnO}$ nanocrystals could serve as $\mathrm{ZnO}$ seeds for the secondary hydrothermal growth of $\mathrm{ZnO}$ NRs [43]. Employing different hydrothermal reaction time of $1,2,4,6$ and $8 \mathrm{~h}$, we successfully fabricated hierarchical NR-on-NS nanostructures with various lengths of new-grown $\mathrm{ZnO}$ NRs. Among the samples with different NR growth time, the $2 \mathrm{~h}$ sample presented a unique coral-like morphology. All the $\mathrm{ZnO}$ films were then electrodeposited with CdSe quantum dots (QDs) to serve as photoanode for QDSSCs. To the best of our knowledge, this is the first time to report QDSSCs based on such hierarchical NR-on-NS ZnO photoanodes. Our results show that, the optimized NR growth time $(6 \mathrm{~h})$ leads to the best photovoltaic performance. When combined with $\mathrm{Cu}_{2} \mathrm{~S}$ counter electrode, the PCE has been further promoted to as high as $4.26 \%$, which is among the highest PCE record for CdSe-sensitized solar cells based on $\mathrm{ZnO}$ photoanodes up till now.

\section{EXPERIMENTAL SECTION}

\section{Preparation of the $\mathrm{V}$-doped $\mathrm{ZnO}$ nanosheet and hierarchical NR-on-NS ZnO films}

Synthesis of the V-doped ZnO NSs was performed according to Gupta's report [42]. Briefly, FTO glass coated with $\mathrm{ZnO}$ seed layer was dipped into an aqueous solution containing $25 \mathrm{mmol} \mathrm{L}^{-1} \mathrm{Zn}\left(\mathrm{NO}_{3}\right)_{2}, 25 \mathrm{mmol} \mathrm{L}^{-1}$ hexamethylenetetramine (HMTA) and $1 \mathrm{mmol} \mathrm{L} \mathrm{L}^{-1} \mathrm{~V}_{2} \mathrm{O}_{5}$, and then it was kept at $90^{\circ} \mathrm{C}$ for $1 \mathrm{~h}$ to attain the NS structures. To fabricate the hierarchical films, the as-prepared NS films were first dipped into a $0.1 \mathrm{~mol} \mathrm{~L}^{-1} \mathrm{Na}_{2} \mathrm{~S}$ solution for $1 \mathrm{~h}$, and then they were taken out and washed with deionized water and ethanol successively. After naturally dried, the films were annealed at $500^{\circ} \mathrm{C}$ for $1 \mathrm{~h}$. Eventually, the films were immersed into a $25 \mathrm{mmol} \mathrm{L}^{-1} \mathrm{Zn}\left(\mathrm{NO}_{3}\right)_{2}, 50$ mmol L ${ }^{-1} \mathrm{HMTA}$ solution and heated to $90^{\circ} \mathrm{C}$, for $1-8 \mathrm{~h}$.

\section{Fabrication of CdSe QDSSCs}

The films were electrodeposited with CdSe quantum dots (QDs) according to our previous report [17]. After CdSe QDs deposition, these photoanodes were sandwiched together with $\mathrm{Pt}$ or $\mathrm{Cu}_{2} \mathrm{~S}$ counter electrodes. The Pt counter electrodes were obtained by dropping $\mathrm{H}_{2} \mathrm{PtCl}_{6}$ solution (5 $\mathrm{mmol} \mathrm{L} \mathrm{L}^{-1}$ in isopropanol) onto FTO glass and successively annealing at $400^{\circ} \mathrm{C}$ for $15 \mathrm{~min}$. The $\mathrm{Cu}_{2} \mathrm{~S}$ counter electrodes were prepared as follows. $0.24 \mathrm{~g}$ anhydrous $\mathrm{CuSO}_{4}$ was dissolved in $60 \mathrm{~mL}$ deionized water and pumped with $\mathrm{N}_{2}$ flow under stirring. After $10 \mathrm{~min}, 0.34 \mathrm{~g}$ sodium thiosulfate was added until it was totally dissolved, then a piece of FTO glass was immersed into the solution at an angle with the conducting side downward. $\mathrm{N}_{2}$ flow was removed and the solution was heated to $90^{\circ} \mathrm{C}$ for $1 \mathrm{~h}$. After $\mathrm{Cu}_{2} \mathrm{~S}$ was deposited onto the FTO surface, the counter electrode was 
rinsed with deionized water and sealed in ethanol. The polysulfide electrolyte was made of $1 \mathrm{~mol} \mathrm{~L}^{-1}$ sulfur powder, $1 \mathrm{~mol} \mathrm{~L}^{-1} \mathrm{Na}_{2} \mathrm{~S}$, and $0.1 \mathrm{~mol} \mathrm{~L}^{-1} \mathrm{NaOH}$ dissolved in methanol/water $(7: 3, v / v)$. The active area of the photoanode films was approximately $0.16 \mathrm{~cm}^{2}$.

\section{Characterization and measurements}

The surface and cross-sectional morphology of the films were examined by field emission scanning electron microscopy (FE-SEM, 6330F, JSM, Japan). Distribution of the elements (elemental mapping) was examined by energy dispersive spectroscopy (EDS). For further structural and phase identification of the films, transmission electron microscopy (TEM, 2010 HR, JEOL, Japan) and X-ray diffractometry (XRD, D8 Advance, Bruker, Germany) were also applied. A UV/vis-NIR spectrophotometer (UV, UV-3150, Shimadzu, Japan) was utilized to investigate the light scattering ability of the bare films and the light harvesting property of the films after deposition of CdSe.

Current density-voltage $(J-V)$ curves of the photoanodes were investigated by utilizing a source meter (2400, Keithley, USA) under simulated AM 1.5 G illumination (100 $\mathrm{mW} \mathrm{cm}^{-2}$ ) provided by a solar simulator (91192, Oriel, USA). The incident photon-to-current efficiency (IPCE) spectra of the samples were examined in the wavelength ranged from 380 to $800 \mathrm{~nm}$ on the basis of a monochromator (DK240, Spectral Products, USA). The electrochemical impedance spectroscopy (EIS) measurement was performed on an electrochemical workstation (Zennium, Zahner, Germany) in dark condition. Applied biases were set to the negative value of $V_{\text {oc }}$ for each photoanode. The amplitude was $10 \mathrm{mV}$ for the bias and the frequency ranged from $0.01 \mathrm{~Hz}$ to $1 \mathrm{MHz}$. Intensity-modulated photocurrent spectroscopy (IMPS) was also carried out on the Zahner-Zennium electrochemical workstation. An intensity modulated $\left(30-150 \mathrm{~W} \mathrm{~m}^{-2}\right)$ blue light emitting diode $(457 \mathrm{~nm})$ driven by a source supply (PP211, Zahner, Germany) was used as the frequency response analyzer. The modulated light intensity was $10 \%$ or less than the base light intensity.

\section{RESULTS AND DISCUSSION}

The morphology and structure of the NSs and hierarchical NR-on-NS films were characterized by FE-SEM, and Figs 1 and 2 show the top-view and cross-sectional SEM images of the samples, respectively.

As shown in Fig. 1a, the V-doped NSs were vertically standing on the FTO glass and were connected to each other in the form of a network. The zoom image also exhibits that the sheets are oriented with various directions
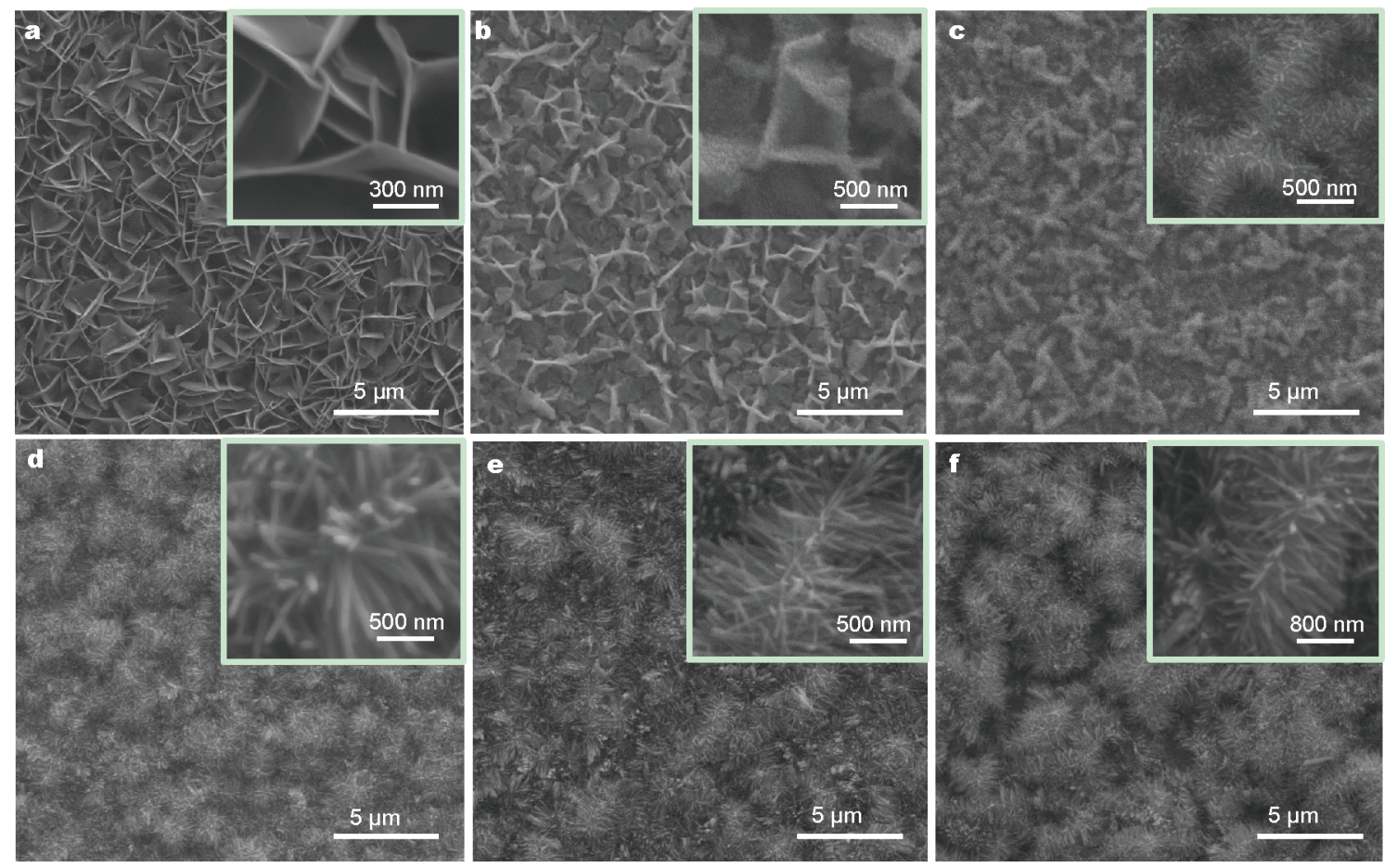

Figure 1 Top-view SEM images of the V-doped NS (a) and hierarchical ZnO films prepared with nanorod growth time of 1, 2, 4, 6 and 8 h (b-f), respectively. 

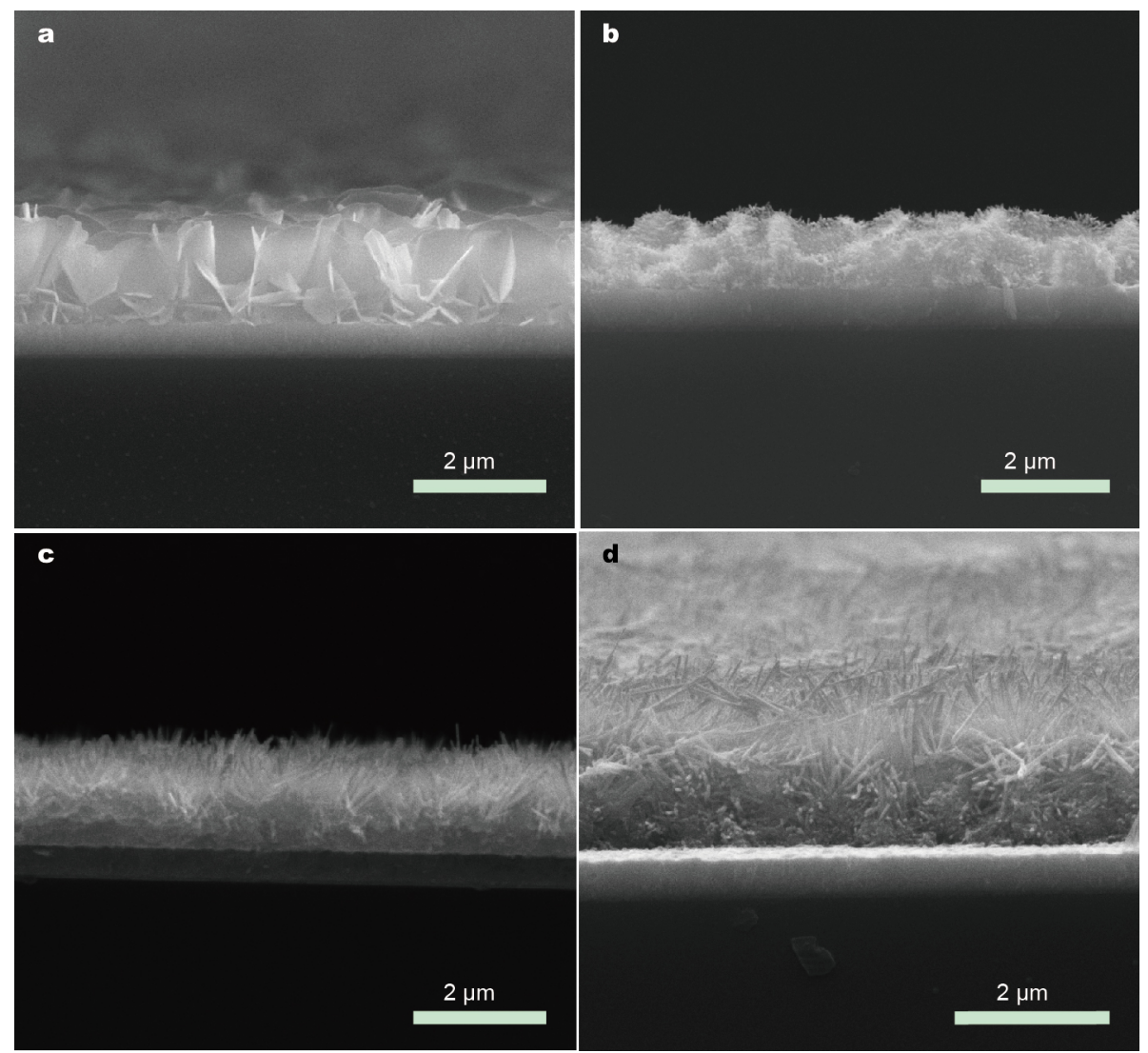

Figure 2 Cross-sectional SEM images of the NS (a), $2 \mathrm{~h} \mathrm{(b),} 6 \mathrm{~h} \mathrm{(c)} \mathrm{and} 8 \mathrm{~h}(\mathrm{~d})$ samples.

and one can clearly see the spaces and voids between adjacent sheets. The thickness of each sheet is estimated to be about $20-30 \mathrm{~nm}$. After treatment with $\mathrm{Na}_{2} \mathrm{~S}$ solution and 1 $\mathrm{h}$ hydrothermal reaction, some parts of the NSs were dissolved. Meanwhile, one can notice that both the bottom of the film and the surface of the sheets become rough, which were coated with lots of nanoparticles (Fig. 1b). When the growth time was lengthened to $2 \mathrm{~h}$ (Fig. 1c), the new-grown nanoparticles evidently turned into nanorods. Most of the NRs (40-70 nm in diameter and $150-220 \mathrm{~nm}$ in length) were grown on both two sides of the NSs with various orientations, which exhibit a unique coral-like morphology. When the hydrothermal process was further prolonged to $4 \mathrm{~h}$ (Fig. 1d), both the length (600-650 nm) and density of the NRs increased rapidly. In this case, it is hardly to see the NS scaffold. The 6 and $8 \mathrm{~h}$ samples have similar appearances to the $4 \mathrm{~h}$ sample (Figs $1 \mathrm{e}$ and $\mathrm{f}$ ), and the NRs in these two samples also grew so dense and long that they concealed the former NSs. The average NR length of the 6 and $8 \mathrm{~h}$ samples reached about $750-800 \mathrm{~nm}$ and $850-900$ $\mathrm{nm}$, respectively. It is worth noting that the diameter of the NRs remained similar ranging from 40 to $70 \mathrm{~nm}$ regardless of different growth time, which indicates that the change in reaction duration can affect only the nanorods branches density and length.

As for the thickness of different $\mathrm{ZnO}$ film, the pristine NS structure with a smooth surface is approximately $1.9 \mu \mathrm{m}$ thick (Fig. 2a). When it was hydrothermally treated for $2 \mathrm{~h}$, a surface transformation from smooth to rough (with numerous tiny rods germinated on the NSs) was observed, and the thickness of the film slightly decreased to about 1.7 $\mu \mathrm{m}$, which was mainly due to the $\mathrm{ZnO}$ corrosion caused by $\mathrm{Na}_{2} \mathrm{~S}$ solution. However, for the 6 and $8 \mathrm{~h}$ samples (Figs $2 \mathrm{c}$ and d), the length of NRs remarkably increased, resulting in enlarging thicknesses of the films to about $2.0-2.2 \mu \mathrm{m}$. It can also be observed that, when the amount and length of NRs increased along with the growth time, the gaps in the bottom of the films were filled compactly. The overcompact part of the film is detrimental for QDs loading and electrolyte penetrating.

Fig. S1 (Supplementary information) presents typical TEM images of the samples. Low and high magnification TEM images of the NS sample are shown in Figs S1a and b, respectively. A clearly resolved lattice fringe can be seen in 
Fig. S1b, and interplanar distance of $0.26 \mathrm{~nm}$ is calculated, which corresponds to the (002) crystallographic planes of $\mathrm{ZnO}$. For the $2 \mathrm{~h}$ sample, short nanorods are covered on the NSs backbone (Fig. S1c). And for the $6 \mathrm{~h}$ sample (Fig. S1d), one can find that the NRs become much denser and longer, forming a fish-bone like structure. The size of the nanorods branches observed from the TEM is in good agreement with previously mentioned SEM results. XRD was also employed for crystalline and phase identification of the samples, which are shown in Fig. S2. Subtracting the diffraction peaks belonging to the $\mathrm{SnO}_{2}$ of FTO substrate, all the other distinguished peaks are identified as a typical wurtzite $\mathrm{ZnO}$ structure (JCPDS Card No. 36-1451). $\mathrm{ZnO}$ diffraction peaks of the NS film are hard to distinguish, which is mainly due to thin thickness and huge interspaces of the film. Along with the lengthened time of NRs modification, $\mathrm{ZnO}$ diffraction peaks become stronger as the density and length of $\mathrm{ZnO}$ NRs increase. Especially, the strongest peak located at $34.4^{\circ}$ can be indexed as the (002) plane of $\mathrm{ZnO}$, indicating that the growth orientation of the $1 \mathrm{D} \mathrm{ZnO}$ branches is along with (001) direction.

To test the proof-of-concept photovoltaic applications of the NS and hierarchical films, CdSe QDs as sensitizers were electrodeposited onto the $\mathrm{ZnO}$ films. Fig. 3a demonstrates the XRD patterns of the $6 \mathrm{~h}$ sample before and after electrodeposition of CdSe QDs. It confirms the existence of cubic CdSe after electrodeposit process, with the two characteristic diffraction peaks appearing at $25.4^{\circ}$ and $42.0^{\circ}$ (JCPDS Card No. 08-0459).

Fig. $3 \mathrm{~b}$ shows the diffuse reflectance spectra of the bare samples. All the hierarchical films show better light scattering ability than the NS film at the range of $380-800 \mathrm{~nm}$, which can be ascribed to the epitaxial growth of branched ZnO NRs on both sides of the NSs scaffolds and such orientations are beneficial for light reflectance. The reflectance rate gradually increases from growth time of 1 to $6 \mathrm{~h}$. However, the reflectance rate of the $8 \mathrm{~h}$ sample is lower than that of the $6 \mathrm{~h}$ sample. The NRs in the $8 \mathrm{~h}$ sample grew even more and longer than in the $6 \mathrm{~h}$ film. As seen in Fig. 2d, the bottom part of the film is filled with excessive NRs and it showcases bulk morphology. Such a compact part diminishes the light scattering ability of the film. Fig. S3 shows the absorption spectra of the samples after CdSe QDs anchoring. The sequence of the absorption value of the samples is the same with that of the reflectance values, that is 6 $\mathrm{h}>8 \mathrm{~h}>4 \mathrm{~h}>2 \mathrm{~h}>1 \mathrm{~h}>$ NS. According to our previous report, the QDs' loading amount in different films is all the same because of identical charge quantity in the electrodeposition process [39]. Thus, the absorption values of different samples are mostly dominated by the light-scattering ability of the films, which is consistent with the diffuse reflectance results. Higher reflectance rate indicates better light-harvesting efficiency, which contributes to higher absorption value.

Fig. 4a exhibits the photocurrent density-photovoltage $(J-V)$ curves of the QDSSCs based on the CdSe sensitized NS or NR-on-NS hierarchical photoanodes combined with Pt counter electrodes. Detailed photovoltaic parameters are listed in Table 1 . The short-circuit current density $\left(J_{\text {sc }}\right)$, open-circuit voltage $\left(V_{\mathrm{oc}}\right)$, fill factor $(\mathrm{FF})$ and power conversion efficiency $(\eta)$ are $2.93 \mathrm{~mA} \mathrm{~cm}{ }^{-2}, 505 \mathrm{mV}, 0.44$ and $0.65 \%$ for the NS sample. The inferior performance of NS sample is mainly due to the limited light scattering ability caused by its smooth surface and sparsely distributed
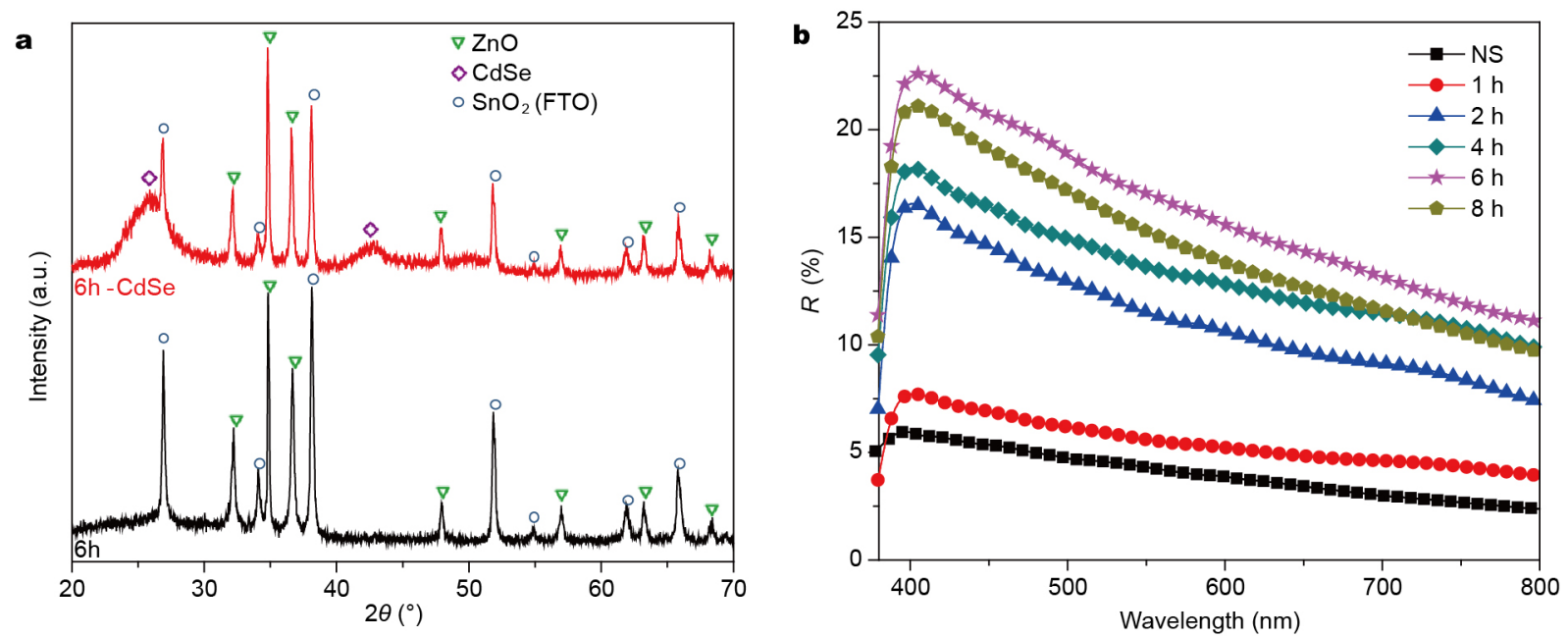

Figure 3 (a) XRD patterns of the $6 \mathrm{~h}$ sample before (black curve) and after (red curve) electrodeposition of CdSe QDs; (b) diffuse reflectance spectra of the bare $\mathrm{ZnO}$ films. 
Table 1 Detailed photovoltaic parameters of QDSSCs fabricated with different ZnO photoanodes and Pt counter electrodes

\begin{tabular}{|c|c|c|c|c|}
\hline Photoanode & $J_{\mathrm{sc}}\left(\mathrm{mA} \mathrm{cm} \mathrm{cm}^{-2}\right)$ & $V_{\mathrm{oc}}(\mathrm{mV})$ & $\mathrm{FF}$ & $\eta(\%)$ \\
\hline NS & 2.93 & 505 & 0.44 & 0.65 \\
\hline $1 \mathrm{~h}$ & 4.63 & 533 & 0.51 & 1.25 \\
\hline $2 \mathrm{~h}$ & 8.37 & 546 & 0.49 & 2.24 \\
\hline $4 \mathrm{~h}$ & 10.95 & 566 & 0.49 & 3.06 \\
\hline $6 \mathrm{~h}$ & 11.75 & 546 & 0.50 & 3.20 \\
\hline $8 \mathrm{~h}$ & 9.38 & 534 & 0.51 & 2.58 \\
\hline
\end{tabular}
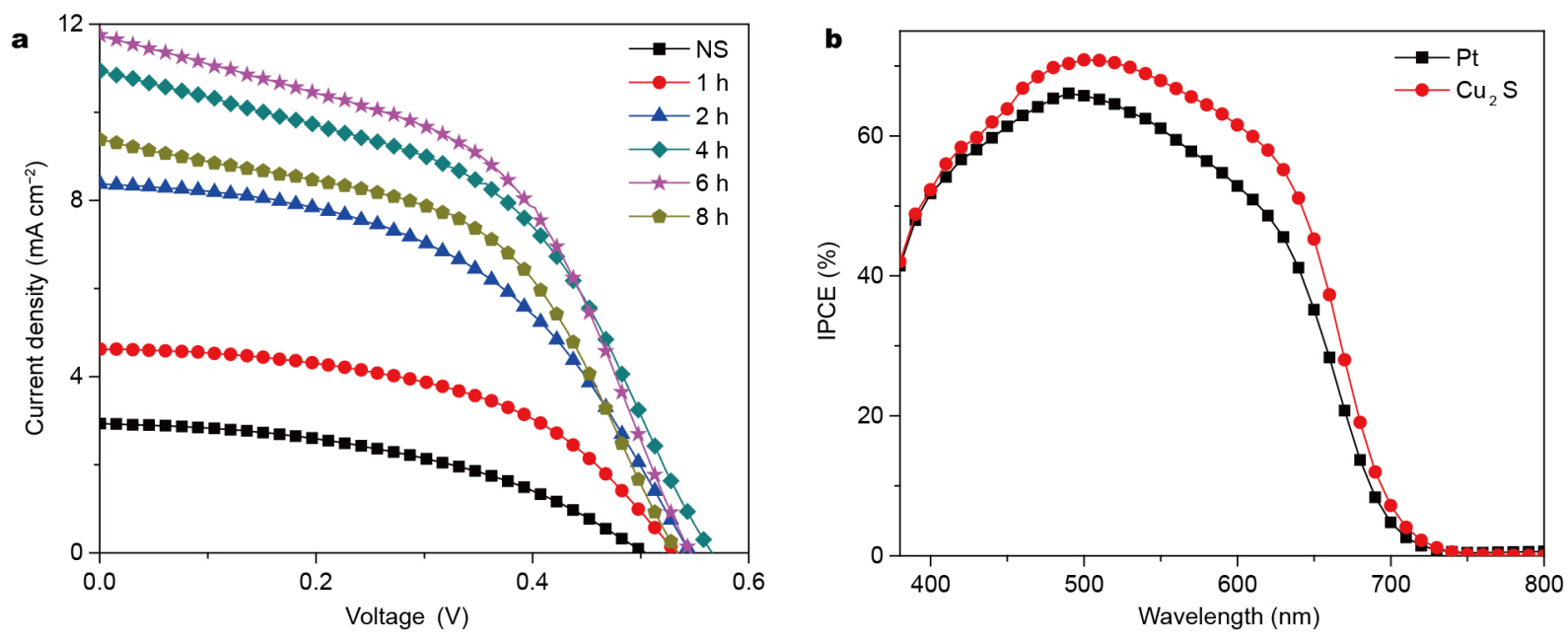

Figure $4 \mathrm{~J}$ - $V$ curves (a) and IPCE curves (b) of the CdSe-sensitized devices based on the ZnO NS and hierarchical samples.

network structure. After grown with additional branched $\mathrm{ZnO}$ structure, all the hierarchical samples show remarkable improvements in QDSSC performances. Firstly, the FFs are all promoted to around 0.50 , and this can be ascribed to the additional growth of $\mathrm{ZnO}$ nanostructures on the FTO surface, which would improve the connection between the $\mathrm{ZnO}$ films and front substrate. Such connection can decrease the charge transfer resistance between $\mathrm{ZnO}$ and FTO. The $J_{\mathrm{sc}}$ increases enormously along with the increasing NR growth time from 1 to $6 \mathrm{~h}$, the highest $J_{\mathrm{sc}}$ value approaches to $11.75 \mathrm{~mA} \mathrm{~cm}^{-2}$ for the $6 \mathrm{~h}$ sample. The remarkable improvement of $J_{\mathrm{sc}}$ is attributed to the tremendous enhancement of excellent light scattering ability and light-harvesting efficiency of the hierarchical NR-on-NS nanostructures. However, $J_{\mathrm{sc}}$ of the $8 \mathrm{~h}$ sample diminishes to $9.38 \mathrm{~mA} \mathrm{~cm}^{-2}$. Besides the weakened light-scattering ability mentioned above, another main reason is that after loaded with CdSe QDs, interspaces at the bottom part of the film become even more compact, thus the electrolyte is hard to penetrate and can not reduce the photo-generated holes promptly. These two factors would result in lower light harvesting efficiency and severer electron re- combination. In addition, the $V_{\text {oc }}$ value increases gradually from 1 to $4 \mathrm{~h}$. The $4 \mathrm{~h}$ sample has the highest $V_{\text {oc }}$ value of $566 \mathrm{mV}$, whereas $V_{\text {oc }}$ value of the samples with growth time longer than $4 \mathrm{~h}$ drops successively. The $V_{\text {oc }}$ is considered to be determined by the two main factors, quasi-Fermi level and electron recombination of the photoanode material [1-3]. Quasi-Fermi level of the photoanode material an shift negatively with the injection of photo-generated electrons. Hence, higher concentration of injected electrons leads to greater shift of the quasi-Fermi level, resulting in higher $V_{\mathrm{oc}}$ value. For the samples prepared with growth time of 1 to $4 \mathrm{~h}$, the improvement of light scattering ability contributes to higher concentration of photo-generated electrons and thus increases the $V_{\text {oc }}$ value. However, larger surface area could meanwhile provide more electron recombination sites. Thus, in the 6 and $8 \mathrm{~h}$ samples, the severe electron recombination neutralizes the high concentration of photo-generated electrons, incurring the decrease of $V_{\text {oc }}$ value. On balance, the $6 \mathrm{~h}$ sample exhibits the highest PCE value (3.20\%) among all the samples, yielding $J_{\text {sc }}, V_{\text {oc }}$ and FF of $11.75 \mathrm{~mA} \mathrm{~cm}^{-2}, 546 \mathrm{mV}$ and 0.50 , respectively. 
IPCE spectra of the samples are shown in Fig. 4b. Evidently, the IPCE values of the QDSSCs based on hierarchical $\mathrm{ZnO}$ samples are higher than that of bare NS counterpart over the wavelength region from 400 to $800 \mathrm{~nm}$. And the value of $8 \mathrm{~h}$ sample drops to between that of the 2 and $4 \mathrm{~h}$ samples, which is consistent with the change of $J_{\text {sc. }}$. It is well known that the IPCE is dominated by light-harvesting efficiency, quantum yield of electron injection and charge collection efficiency. Herein, higher IPCE values can be ascribed to the better light-harvesting efficiency as discussed above. Moreover, compared with the NS sample, the IPCE values of the hierarchical samples, especially that with growth time up to $2 \mathrm{~h}$, display an obvious red-shift to a longer wavelength of about 550-700 nm. This result indicates the effectiveness of the improved light scattering ability of the hierarchical samples, which also contributes to the enhancement of IPCE and $J_{\text {sc }}$ values.

EIS measurement was applied to study the interfacial charge transfer process of the samples [40]. Fig. 5a displays the Nyquist plots of the NS and hierarchical photoanodes. All the samples exhibit defined semicircles in the low frequency, which corresponds to the electron transfer resistance at the $\mathrm{ZnO} / \mathrm{QD}$ s/electrolyte interface. The NS sample shows the largest semicircle, and the simulated value of resistance is $1014 \Omega$. The hierarchical samples have smaller semicircles and the simulated resistance values decrease with the lengthened growth time. Simulated resistance values are 972, 479, 434, 418 and $407 \Omega$ for the 1-8 h samples, respectively. Lower simulated resistance values reflect severer charge recombination at the $\mathrm{ZnO} / \mathrm{QDs} /$ electrolyte interface. Along with the lengthened growth time, surface area of the films increased, which resulted in more trapping sites for much more serious

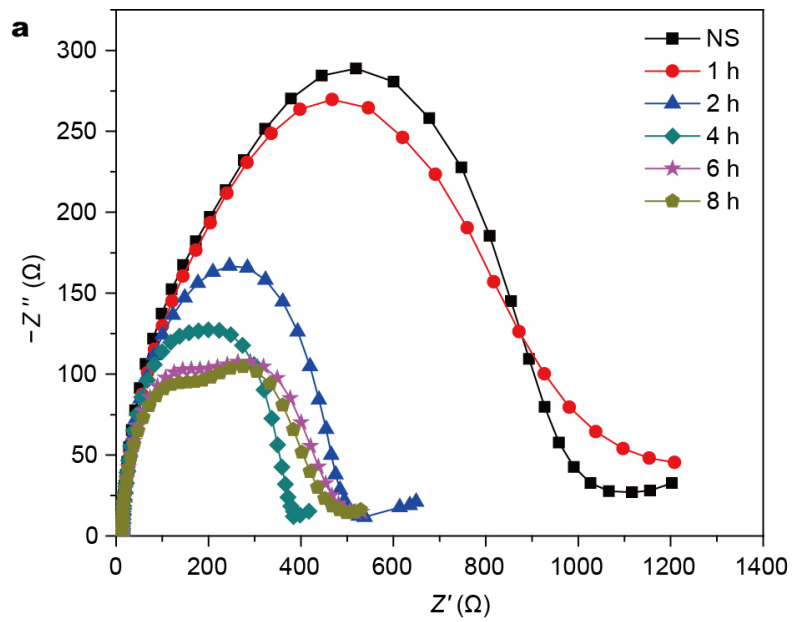

electron recombination.

IMPS has been verified as a convincing technique for investigating the electron transport [41]. The transport time $\tau_{\mathrm{d}}$ can be calculated by the equation $\tau_{\mathrm{d}}=1 /\left(2 \pi f_{\mathrm{IMPS}}\right)$, where $f_{\text {IMPS }}$ is the characteristic minimum frequency of the IMPS imaginary component, and the calculated $\tau_{\mathrm{d}}$ result as a function of light intensities is displayed in Fig. $5 b$. It reveals that the NS sample has the longest transport time, meaning the slowest electron transport property. For the hierarchical samples, the electron transport becomes faster along with prolonged growth time from 1 to $6 \mathrm{~h}$, and the $8 \mathrm{~h}$ sample shows slower electron transport than the $4 \mathrm{~h}$ sample. Herein, faster electron transport can reflect higher photo-generated electron concentration, which is attributed to better light-harvesting efficiency. Moreover, the higher photo-generated electron concentration can also shift the quasi-Fermi level negatively, and further promote the $V_{\text {oc }}$ value. Thus, the IMPS measurement proves that the $V_{\text {oc }}$ values increase from NS to $4 \mathrm{~h}$ sample because of the enhancement of light-harvesting efficiency. For the 6 and $8 \mathrm{~h}$ samples, the severe electron recombination counteracts the enhancement of light-harvesting efficiency, bringing about the diminishment of $V_{\mathrm{oc}}$.

It is commonly considered that $\mathrm{Cu}_{2} \mathrm{~S}$ counter electrodes exhibit higher electrocatalytic activities than the Pt counter electrodes in polysulfide electrolyte [42]. We combined the $\mathrm{CdSe}$-sensitized $6 \mathrm{~h}$ photoanode with a $\mathrm{Cu}_{2} \mathrm{~S}$ counter electrodes for $J-V$ curves examination. As shown in Fig. 6, the QDSSC utilizing $\mathrm{Cu}_{2} \mathrm{~S}$ counter electrode exhibits overall improvement in $J_{\mathrm{sc}}\left(12.67 \mathrm{~mA} \mathrm{~cm}^{-2}\right), V_{\text {oc }}(580 \mathrm{mV})$ and $\mathrm{FF}$ (0.58). The eventual PCE value reached $4.26 \%$, which was increased by $33 \%$ compared with the Pt counter elec-trode based cell.

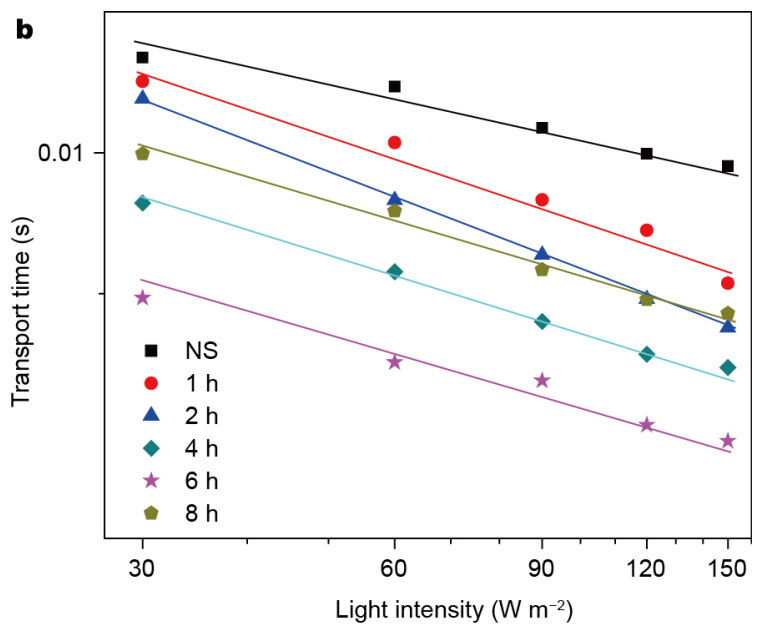

Figure 5 EIS spectra (a) and electron transport time constants (b) measured by the IMPS test of the cells based on the NS and hierarchical samples. 


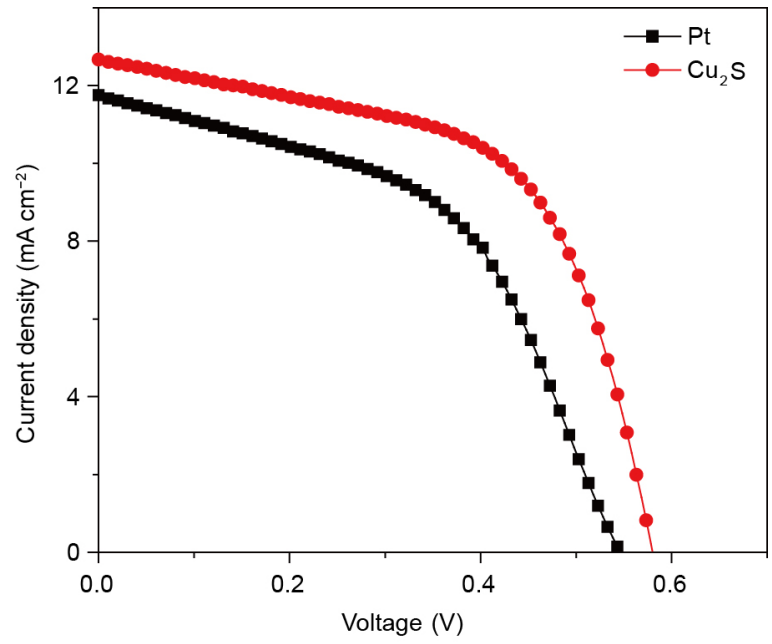

Figure 6 Comparison of the $J-V$ curves of QDSSCs combined with the 6 $\mathrm{h}$ photoanode with $\mathrm{Pt}$ or $\mathrm{Cu}_{2} \mathrm{~S}$ counter electrodes.

\section{CONCLUSIONS}

We prepared a well-aligned and well-interconnected 2D $\mathrm{ZnO}$ NS film and successfully converted it into a hierarchical NR-on-NS structure via $\mathrm{Na}_{2} \mathrm{~S}$ solution treatment followed by subsequent hydrothermal reaction. Such NS and hierarchical samples were sensitized with CdSe QDs and their photovoltaic performances were investigated in detail. The hierarchical samples prepared with different NR growth time all exhibited higher PCE values than the NS sample, which could be attributed to the enormous enhancement of light-scattering ability and further light-harvesting efficiency in the hierarchical films. For the hierarchical films, the enhanced light-harvesting efficiency could remarkably promote the photo-generated electron concentration, which could improve both the $J_{\mathrm{sc}}$ and $V_{\mathrm{oc}}$ values. However, over-reacted film $(8 \mathrm{~h})$ was detrimental for lightharvesting and resulted in severe electron recombination. With the optimized $\mathrm{ZnO}$ NR-on-NS samples (6h) and $\mathrm{Cu}_{2} \mathrm{~S}$ counter electrode, the PCE was further boosted to $4.26 \%$, which is among the highest PCE record for CdSe sensitized solar cells based on $\mathrm{ZnO}$ photoanodes up to now.

Received 18 July 2016; accepted 13 August 2016; published online 20 September 2016

1 Grätzel M. Photoelectrochemical cells. Nature, 2001, 414: 338-344

2 Kamat PV, Tvrdy K, Baker DR, et al. Beyond photovoltaics: semiconductor nanoarchitectures for liquid-junction solar cells. Chem Rev, 2010, 110: 6664-6688

3 Nozik AJ, Beard MC, Luther JM, et al. Semiconductor quantum dots and quantum dot arrays and applications of multiple exciton generation to third-generation photovoltaic solar cells. Chem Rev, 2010, 110: 6873-6890
$4 \mathrm{Xu}$ J, Chen Z, Zapien JA, et al. Surface engineering of $\mathrm{ZnO}$ nanostructures for semiconductor-sensitized solar cells. Adv Mater, 2014, 26: 5337-5367

$5 \mathrm{Du}$ J, Du Z, Hu JS, et al. Zn-Cu-In-Se quantum dot solar cells with a certified power conversion efficiency of $11.6 \%$. J Am Chem Soc, 2016, 138: 4201-4209

6 Yu XY, Liao JY, Qiu KQ, et al. Dynamic study of highly efficient CdS/CdSe quantum dot-sensitized solar cells fabricated by electrodeposition. ACS Nano, 2011, 5: 9494-9500

7 Rao HS, Wu WQ, Liu Y, et al. CdS/CdSe co-sensitized vertically aligned anatase $\mathrm{TiO}_{2}$ nanowire arrays for efficient solar cells. Nano Energy, 2014, 8: 1-8

8 Yang J, Wang J, Zhao K, et al. CdSeTe/CdS type-I core/shell quantum dot sensitized solar cells with efficiency over 9\%. J Phys Chem C, 2015, 119: 28800-28808

9 Ren F, Li S, He C. Electrolyte for quantum dot-sensitized solar cells assessed with cyclic voltammetry. Sci China Mater, 2015, 58: 490-495

10 Leschkies KS, Divakar R, Basu J, et al. Photosensitization of $\mathrm{ZnO}$ nanowires with CdSe quantum dots for photovoltaic devices. Nano Lett, 2007, 7: 1793-1798

11 Xu J, Yang X, Wang $\mathrm{H}$, et al. Arrays of $\mathrm{ZnO} / \mathrm{Zn}_{x} \mathrm{Cd}_{1-x}$ Se nanocables: band gap engineering and photovoltaic applications. Nano Lett, 2011, 11: 4138-4143

12 Tian J, Zhang Q, Uchaker E, et al. Architectured $\mathrm{ZnO}$ photoelectrode for high efficiency quantum dot sensitized solar cells. Energy Environ Sci, 2013, 6: 3542-3547

13 Yan K, Zhang L, Qiu J, et al. A quasi-quantum well sensitized solar cell with accelerated charge separation and collection. J Am Chem Soc, 2013, 135: 9531-9539

14 Hossain MA, Jennings JR, Koh ZY, et al. Carrier generation and collection in CdS/CdSe-Sensitized $\mathrm{SnO}_{2}$ solar cells exhibiting unprecedented photocurrent densities. ACS Nano, 2011, 5: 3172-3181

15 Xiao J, Huang Q, Xu J, et al. CdS/CdSe co-sensitized solar cells based on a new $\mathrm{SnO}_{2}$ photoanode with a three-dimensionally interconnected ordered porous structure. J Phys Chem C, 2014, 118: 4007-4015

16 Li Y, Pang A, Zheng X, et al. CdS quantum-dot-sensitized $\mathrm{Zn}_{2} \mathrm{SnO}_{4}$ solar cell. Electrochim Acta, 2011, 56: 4902-4906

17 Li LB, Wang YF, Rao HS, et al. Hierarchical macroporous $\mathrm{Zn}_{2} \mathrm{SnO}_{4-}$ $\mathrm{ZnO}$ nanorod composite photoelectrodes for efficient CdS/CdSe quantum dot co-sensitized solar cells. ACS Appl Mater Interf, 2013, 5: 11865-11871

18 Wang J, Li Y, Shen Q, et al. Mn doped quantum dot sensitized solar cells with power conversion efficiency exceeding $9 \%$. J Mater Chem A, 2016, 4: 877-886

19 Ren Z, Wang J, Pan Z, et al. Amorphous $\mathrm{TiO}_{2}$ buffer layer boosts efficiency of quantum dot sensitized solar cells to over $9 \%$. Chem Mater, 2015, 27: 8398-8405

20 Zhao K, Pan Z, Mora-Seró I, et al. Boosting power conversion efficiencies of quantum-dot-sensitized solar cells beyond $8 \%$ by recombination control. J Am Chem Soc, 2015, 137: 5602-5609

21 Ren Z, Wang Z, Wang R, et al. Effects of metal oxyhydroxide coatings on photoanode in quantum dot sensitized solar cells. Chem Mater, 2016, 28: 2323-2330

22 Anta JA, Guillén E, Tena-Zaera R. Zno-based dye-sensitized solar cells. J Phys Chem C, 2012, 116: 11413-11425

23 Park WI, Kim JS, Yi GC, et al. Fabrication and electrical characteristics of high-performance $\mathrm{ZnO}$ nanorod field-effect transistors. Appl Phys Lett, 2004, 85: 5052-5054 
24 Breckenridge RG, Hosler WR. Electrical properties of titanium dioxide semiconductors. Phys Rev, 1953, 91: 793-802

$25 \mathrm{Xu} \mathrm{C}, \mathrm{Wu}$ J, Desai UV, et al. Multilayer assembly of nanowire arrays for dye-sensitized solar cells. J Am Chem Soc, 2011, 133: 8122-8125

26 Elias J, Tena-Zaera R, Wang GY, et al. Conversion of $\mathrm{ZnO}$ nanowires into nanotubes with tailored dimensions. Chem Mater, 2008, 20: 6633-6637

27 Qi X, She G, Liu Y, et al. Electrochemical synthesis of CdS/ZnO nanotube arrays with excellent photoelectrochemical properties. Chem Commun, 2012, 48: 242-244

28 Liu Q, Jiang L, Guo L. Precursor-directed self-assembly of porous $\mathrm{ZnO}$ nanosheets as high-performance surface-enhanced raman scattering substrate. Small, 2014, 10: 48-51

29 Lin CY, Lai YH, Chen HW, et al. Highly efficient dye-sensitized solar cell with a $\mathrm{ZnO}$ nanosheet-based photoanode. Energy Environ Sci, 2011, 4: 3448-3455

30 Li F, Ding Y, Gao P, et al. Single-crystal hexagonal disks and rings of $\mathrm{ZnO}$ : low-temperature, large-scale synthesis and growth mechanism. Angew Chem Int Ed, 2004, 43: 5238-5242

31 Wang X, Liao M, Zhong Y, et al. ZnO hollow spheres with doubleyolk egg structure for high-performance photocatalysts and photodetectors. Adv Mater, 2012, 24: 3421-3425

32 Dong Z, Lai X, Halpert JE, et al. Accurate control of multishelled $\mathrm{ZnO}$ hollow microspheres for dye-sensitized solar cells with high efficiency. Adv Mater, 2012, 24: 1046-1049

33 Zheng YZ, Ding H, Liu Y, et al. In situ hydrothermal growth of hierarchical $\mathrm{ZnO}$ nanourchin for high-efficiency dye-sensitized solar cells. J Power Sources, 2014, 254: 153-160

34 Ko SH, Lee D, Kang HW, et al. Nanoforest of hydrothermally grown hierarchical $\mathrm{ZnO}$ nanowires for a high efficiency dye-sensitized solar cell. Nano Lett, 2011, 11: 666-671

35 Cheng HM, Chiu WH, Lee CH, et al. Formation of branched $\mathrm{ZnO}$ nanowires from solvothermal method and dye-sensitized solar cells applications. J Phys Chem C, 2008, 112: 16359-16364

36 Labouchere P, Chandiran AK, Moehl T, et al. Passivation of $\mathrm{ZnO}$ nanowire guests and $3 \mathrm{D}$ inverse opal host photoanodes for dyesensitized solar cells. Adv Energy Mater, 2014, 4: 1400217

37 Zhang J, He M, Fu N, et al. Facile one-step synthesis of highly branched $\mathrm{ZnO}$ nanostructures on titanium foil for flexible dye-sensitized solar cells. Nanoscale, 2014, 6: 4211-4216

38 Gao R, Tian J, Liang Z, et al. Nanorod-nanosheet hierarchically structured $\mathrm{ZnO}$ crystals on zinc foil as flexible photoanodes for dye-sensitized solar cells. Nanoscale, 2013, 5: 1894-1901
39 Gao R, Cui Y, Liu X, et al. A ZnO nanorod/nanoparticle hierarchical structure synthesized through a facile in situ method for dye-sensitized solar cells. J Mater Chem A, 2014, 2: 4765-4770

40 Kim H, Yong K. A highly efficient light capturing 2D (nanosheet)-1D (nanorod) combined hierarchical $\mathrm{ZnO}$ nanostructure for efficient quantum dot sensitized solar cells. Phys Chem Chem Phys, 2013, 15: 2109-2116

41 Dai H, Zhou Y, Chen L, et al. Porous ZnO nanosheet arrays constructed on weaved metal wire for flexible dye-sensitized solar cells. Nanoscale, 2013, 5: 5102-5108

42 Gupta MK, Lee JH, Lee KY, et al. Two-dimensional vanadiumdoped $\mathrm{ZnO}$ nanosheet-based flexible direct current nanogenerator. ACS Nano, 2013, 7: 8932-8939

43 Zhang X, Liu Y, Kang Z. 3D branched zno nanowire arrays decorated with plasmonic Au nanoparticles for high-performance photoelectrochemical water splitting. ACS Appl Mater Interf, 2014, 6: 4480-4489

44 Wang Q, Ito S, Grätzel M, et al. Characteristics of high efficiency dye-sensitized solar cells. J Phys Chem B, 2006, 110: 25210-25221

45 van de Lagemaat J, Park NG, Frank AJ. Influence of electrical potential distribution, charge transport, and recombination on the photopotential and photocurrent conversion efficiency of dye-sensitized nanocrystalline $\mathrm{TiO}_{2}$ solar cells: a study by electrical impedance and optical modulation techniques. J Phys Chem B, 2000, 104: 2044-2052

46 Jiang $\mathrm{Y}$, Zhang $\mathrm{X}, \mathrm{Ge} \mathrm{QQ}$, et al. ITO@ $\mathrm{Cu}_{2} \mathrm{~S}$ tunnel junction nanowire arrays as efficient counter electrode for quantum-dot-sensitized solar cells. Nano Lett, 2014, 14: 365-372

Acknowledgments This work was supported by the National Natural Science Foundation of China (51472274), the Program of Guangzhou Science and Technology (2014J4100016 and 201504010031), the Pearl River S\&T Nova Program of Guangzhou (2014J2200025), and the Natural Science Foundation of Guangdong Province (S2013030013474).

Author contributions Li L designed and performed the experiments; $\mathrm{Li} \mathrm{L}$ wrote the paper with support from Wu W, Chen $\mathrm{H}$ and Kuang D. Rao $\mathrm{H}$ and Feng $\mathrm{H}$ provided help in the methods of characterization. Chen $\mathrm{H}$ and Kuang D supervised the projects and carefully reviewed and modified this manuscript. All authors contributed to the general discussion.

Conflict of interest The authors declare that they have no conflict of interest.

Supplementary information Supplementary data are available in the online version of the paper. 

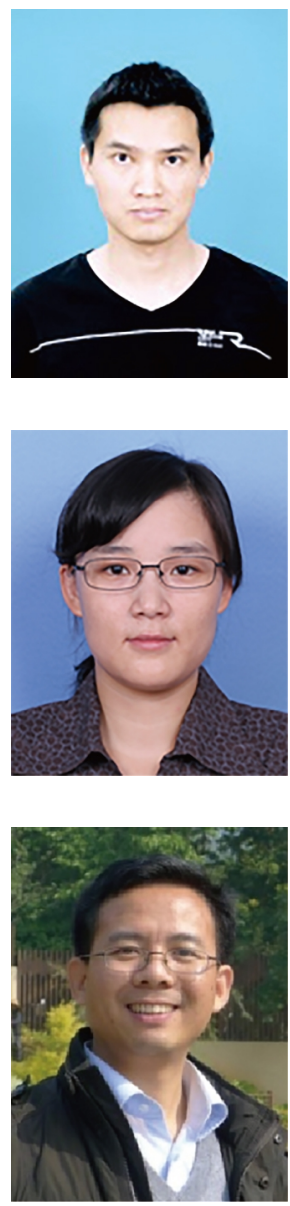

Long-Bin Li received his Bachelor's degree from Sun Yat-sen University (SYSU) in 2011. Now he is a PhD student at the School of Chemistry, SYSU. His research interest is focused on $\mathrm{ZnO}$ and $\mathrm{Zn}_{2} \mathrm{SnO}_{4}$ nanomaterials and their applications in quantum dot-sensitized solar cells.
Hong-Yan Chen is an associate professor at SYSU. She received her Bachelor's degree in 2005 from the Northeast Normal University, and her PhD in physical chemistry from the Institute of Chemistry Chinese Academy of Sciences (ICCAS) in 2010. Her current research interest lies in the functional micro/nanostructured materials for dye-sensitized solar cells, photocatalysis and photoelectrochemical cells.

Dai-Bin Kuang is a professor at SYSU. Dr. Kuang received his PhD degree from SYSU in 2003. He worked at Max Planck Institute of Colloids and Interfaces (Germany) from 2003 to 2004 and then at Ecole Polytechnique Fédérale de Lausanne (Switzerland) from 2004 to 2008 as postdoctoral researcher. His current research interest is in the field of new energy materials, focusing on functional nanostructured materials and their applications in dye-sensitized/quantum dot-sensitized solar cells, perovskite solar cells, photocatalysis and photoelectrochemical cells.

\section{分等级氧化锌纳米片-纳米棒电极高效硒化镉量子点敏化太阳电池}

李龙斌, 吴武强, 饶华商, 陈洪燕“, 冯浩霖, 匡代樹 ${ }^{*}$ 苏成勇

摘要 本文首先以水热反应法获得了掺钒的 $\mathrm{ZnO}$ 纳米片薄层, 然后通过 $\mathrm{Na}_{2} \mathrm{~S}$ 处理和进一步的水热反应在纳米片表面生长出 $\mathrm{ZnO}$ 纳米棒分 支结构, 以此获得了一种新颖独特的 $\mathrm{ZnO}$ 纳米片-纳米棒三维分等级结构. $\mathrm{ZnO}$ 纳米棒分支结构的引入, 有效地提高了光阳极薄膜的漫反射 性能. 随后利用电沉积法沉积 CdSe 量子点研究了其光电化学性能, 基于分等级结构光阳极的 CdSe 量子点敏化太阳电池(QDSSC)的短路电 流密度、开路电压以及最终的光电转换效率都比 $\mathrm{ZnO}$ 纳米片光阳极有了显著提升. 详细分析了不同的 $\mathrm{ZnO}$ 纳米棒分支生长时间 $(1,2,4,6$ 和 $8 \mathrm{~h}$ ) 对器件光电性能的影响. 测试结果显示, $\mathrm{ZnO}$ 纳米棒生长时间为 $6 \mathrm{~h}$ 所得的分等级样品获得了最高的光电转换效率, 在与 $\mathrm{Cu}_{2} \mathrm{~S}$ 对电极 组装成QDSSC 时效率达到了 $4.26 \%$. 